in an old Institute not too well equipped for the purpose, and he was confronted with a foreign tongue. Without a trace of hesitation, he solved all problems speedily and elegantly, while at the same time he was, from the beginning, actively concerned with various aspects of geneties in The Netherlands, including the editing of the journal Genetica. Ho and his family were on the way to becoming true Dutchmen, except perhaps for the inborn necessity of a sabbatical retreat. The irresistible call to Swansea clearly came at the right time, although it is not a propitious one to genetics in The Netherlands, and the move is a disappointment to Dutch colleagues.

\section{More German Research Funds}

GovernMent expenditure on scientific research is to be increased in 1966 by about 30 por cent compared with 1965. Tho budget of the Ministry for Scientific Research, now published, shows that the expenditure planned for 1966 is the equivalent of $£ 116$ million. This sum is, of course, separate from that spent on seientific research and development by other agencies of the West German Government. In 1965 it is estimated that a total of about 2 per cent of the West German gross national product was spent on scientific research and development, which implies an expenditure cquivalent to $£ 800$ million a year.

On the funds available at the Ministry for Scientific Research during $1966, £ 32$ million will be spent on tho expansion of universities and other establishments of higher education, $£ 44$ million for the support of nuclear energy for peaceful purposes, and a total of more than $£ 22$ million on space research, including the developmont and construction of a German Earth satellite.

\section{Grants for Industrial Scientists}

The Science Research Council in the United Kingdom has announced two schemes clearly intendod to make it easier for industrial scientists to obtain furthor training and postgraduate qualifications. Thus the Council has announced a new scheme of industrial studentships for which young scientists working in industry are eligible. Theso awards will be available either for 6- or 12-month courses for advanced training, or for longer periods of up to 3 years for training in research normally leading to a higher degroe. The schome will start in October 1966 and it is thought that at least a hundred awards will be made. To obtain an award an industrial scientist must have been employed professionally for at least a year, and must also be academically suitable in the eyes of the Science Research Council and the intending university or colloge of advanced technology. The most wolcome innovation in the new scheme may be that the Science Research Council has decided that industrial employers (if they wish) can supplement the amount of an industrial studentship so as to increase the student's income to that which he would have received at his job.

The second scheme devised by the Science Research Council is intended to encourage young graduates in science and technology to gain industrial experience before embarking on postgraduate training. The intention is that suitable young graduates should be given a guarantee of support from the Scienco Research Council for a course of postgraduate study to begin at any time from 1 to 5 years after graduation. The Council hopes this arrangement will enable young graduates to start an industrial career and to undertake further academic training at what they and their employers consider the most suitable time. Here, again, the Science Research Council hopes that employers will give their moral and financial blessing to further education.

Obviously the success of both ventures will be detormined partly by tho willingness of industrial companies to respond and partly by the willingness of young graduates, together with universities and eolleges of advanced technology, to acknowledge that a ready exchange of people between academic life and industry can be advantageous. Thus even if the schemes should not-as the Science Research Council hopes-enhance the academic background of industrial sciontists, they will provide a searching test of the honesty of recent protestations of goodwill towards industry by academic institutions.

\section{Institute of Geological Sciences}

A NEW organization called the Institute of Geological Sciences has been formed in Britain by the National Environment Research Council. 'The Institute is really an amalgam of the Geological Survey in Great Britain, the Museum of Practical Geology and the Overseas Geological Surveys. These organizations have worked closely together ever since the formation of the National Environment Council which followed the recommendation of the Brundrett Committee in uniting the home and overseas geological surveys in June 1965. The National Environment Resoarch Council hopes that the title of the geological institute will emphasize the breadth and the range of scientific diseiplines used in modern geological survey and research. It is intended to extend the field of activity of the existing organizations under the guidance of the Geology and Geophysics Committee of the Council, and steps are also being taken to see how best the headquarters of the new organization (but not the Museum) can be moved out of London.

\section{Strontium-90 Levels in Australia, 1961-63}

THe Atomic Weapons Tests Safety Committee in Australia has published the results of a survey of the amount of strontium-90 in the Australian environment during 1961-63 (Austral. J. Sci., 28, No. 2; 1965). Strontium-90 fall-out over Australia during the period under review arose from nuclear weapons tests carricd out in the Northern Hemisphere before 1959, and from the U.S.S.R. and United States test series of 1961-62, the total and fission yields of which were greater than those from all previous tests. Until the middle of 1962 , there was no significant fall-out over Australia from tests later than 1958. During the remainder of the period under review, increasing levels of fall-out were recorded; thoy havo been attributed mainly to the United States programme in the North Pacific Ocean during 1962, but towards the end of 1963 strontium-90 from tests by the U.S.S.R. may have been making a significant contribution. It is expected that all fall-out over Australia from nuclear weapons tests held during 1961-62 will oventually be comparable with that from all previous testing. The mean annual deposition of strontium-90 in precipitation at the chosen monitoring sites in Australia remained in the region of $1 \mathrm{mc} . / \mathrm{km}^{2}$ from 1958 to 1962 but rose to about $1.5 \mathrm{mc} . / \mathrm{km}^{2}$ in 1963 . Regular differences in the annual strontium-90 fall-out between the sites are now well established: during the period of constant fall-out (1958-62), Townsville was lowest at $0.4 \mathrm{mc} . \mathrm{km}^{2}$ per annum and Sydney highest at $1.3 \mathrm{mc} . / \mathrm{km}^{2}$ per annum, with the other stations in between in the ascending order, Darwin, Perth, Hobart, Adelaide, Melbourne and Brisbano. These levels are comparable with those for the period before 1960 , as assessed by the National Radiation Advisory Committee. Levels of strontium-90 in Australian human bone are lower than those in the populations of the United Kingdom and the United States. However, it is of interest that the ratio of strontium-90 to calcium in bone tissue or in total diet, relative to the level of strontium-90 in precipitation, is higher in Australia than in the United Kingdom or the United States. Although fall-out levels continue to be much lower in Australia than in the United Kingdom and the United States, examination of substantial bodies of data indicates that the transfer of strontium-90 from fall-out through the food-chain to diet may be approximately twice as efficient in the Australian environment as in the United 